\title{
3 Crossing the Channel: Publishing Translated German 4 Fiction in the UK
}

\author{
5 Corinna Norrick-Rühl ${ }^{1} \cdot$ Melanie Ramdarshan Bold $^{2}$
}

6

7 C Springer Science+Business Media New York 2016

8 Abstract In a review of Hans Fallada's novel Alone in Berlin-finally translated 9 into English after 62 years-Sam Jordison stated, "[I]t's an important book that no 10 English writer could have written-and so another resounding argument for the 11 importance of taking in translations. It makes me wonder what else we've been 12 missing." Translated fiction plays a minimal role in the UK. Scholars are increas13 ingly directing their attention towards this deficit. This paper will consider the 14 culture of translation in the UK and Ireland, with a particular focus on translated 15 German fiction.

19 Keywords Translation · Publishing · Independent publishing · Literary prizes ·

28 Germany $\cdot$ UK

In his book Is That a Fish in Your Ear? The Amazing Adventure of Translation [4] 22 David Bellos based some of his observations on the UNESCO's Index Transla23 tionum [62], which has collected worldwide translation data since 1932. ${ }^{1}$ Bellos shows that while English is the most frequently used language, there is a clear imbalance regarding English as a source and English as a target language for translations. While one-tenth of the translations recorded in the Index are translations into English, two-thirds are translations from the English. As Bellos the data is not collected by UNESCO, but rather delivered to UNESCO by the countries themselves, usually via the national trade organizations. However, since there is no comparable database, it is a very valuable go-to-resource for scholars as well as industry practitioners.
A1 $\square$ Corinna Norrick-Rühl
A2 norrick@uni-mainz.de
A3 1 Institute for Book Studies, Johannes Gutenberg University, 55099 Mainz, Germany
A4 2 Department of Information Studies, University College London, Gower Street,
A5 London WC1E 6BT, UK 
showed, "Nearly 80 per cent of all translations done in all directions between these seven languages [Swedish, Chinese, Hindi, Arabic, French, German, English] over a decade [2000-2009] - 104,000 out of 132,000 - are translations from English. Conversely, barely more than 8 per cent of all translations done in the same set are translations into English". Translations from English, Bellos continued, "are all over the place; translations into English are as rare as hen's teeth" [5]. While the asymmetrical structure of the global translations market is firmly embedded in our system of economic hierarchy, as Norbert Bachleitner and Michaela Wolf stated in 2010, and the translation flow mirrors the commodity flow [2], Bellos warned that it is "neither accurate nor interesting to pin the responsibility for our lop-sided translation world on the Almighty Dollar alone" [6].

Being published in English is a prestigious accolade for foreign authors, even if they usually make more money on royalties from other countries. As Lepape maintained:

Frankfurt [Book Fair] reflects the increasingly one-way flow of trade between the United States and its sidekick, Britain, and the rest of the Western world. French, Spanish, Italian and German publishers all go to the fair with a single and near-impossible dream: to sell a book to the Americans even for a derisory amount, or to a British publisher as a first step to the paradise of the US market. They all know that this is a false hope [41].

Although Lepape portrays British publishers and the readers as 'junior partners' in the global market for translations, in this case study, we would like to focus on the culture of translation between Germany and the UK nonetheless. There is already some research available on the relationship between Germany and the Englishspeaking world more generally, in particular the US book industry, for instance Bender [7], Jahnsen [34], Rectanus [51], Smerillo [54, 55] and Kessel [36], though this certainly merits further attention as well. We believe that the special relationship between the UK and Germany, defined by antagonism and cooperation in the past, present, and future, make this case study particularly worthwhile. The German and British publishing industries are also two of the largest, most active, and most established in Europe, as evidenced by their output, amongst other things. According to the most recently published European book publishing statistics, the British and German book industries are the "largest markets in terms of publishers' turnover" (Germany coming in first, UK second), the two "countries reporting the largest availability" of titles in stock (UK coming in first, Germany second) and the "largest new titles output" (UK, then Germany) [24]. Additionally, the London and Frankfurt book fairs are two of the biggest book fairs in the world and are both very important in the international trade of rights [46]. These internationally-established book fairs are evidence that the UK and German publishing industries are committed to participating in the international publishing industry, and thus to communicating on a global scale. Finally, both countries also have a rich literary and publishing history, and are dynamic contributors to the global cultural economy. In her recent monograph Förderung literarischer Übersetzung in Deutschland, Slávka Rude-Proubská notes that there are serious shortcomings regarding research on translation in general, but especially on the promotion of literary translation. She 
elaborates that there is hardly any empirical data, there are no systematic studies or parameters for analysis of the existing funding instruments and so far, research has all but ignored the principles and policies behind the funding bodies involved [53]. This contribution (and our larger project) aim(s) to better understand the actors, institutions and stakeholders in the market for translations between the UK and Germany. ${ }^{2}$

\section{Statistics and Status Quo}

"The role of English is that of a bottleneck and a driving force," and English, but also German and French, can be considered the most important "transfer language[s]" [37]. German, however, is more than just a transfer language for literature from other languages into English. It is also an important and successful source language in its own right. The most important genres for rights sales are children's and young adult books (in 2014, $36.7 \%$ of all translations from the German came from this genre) and fiction (18.6\% in 2014) [10]. China reigns supreme as the main buyer of German rights with almost 1000 contracts in 2014 alone. Chinese publishers are especially interested in buying German children's and young adult literature. France trails behind in second place with only 334 contracts in 2014. No English-speaking country has made it into the top ten for years, but English as a target language placed second in 2014 with 450 contracts in 2014 (as a comparison: Spanish had 426 contracts in 2014) [13]. The high level of detail that Buch und Buchhandel in Zahlen offers regarding translation statistics shows that translations are highly regarded and much sought-after in the German book industry. On the other hand, the British equivalent, the Publishers Association Statistics Yearbook, only discusses translations in regards to the percentage of complete industry rights income that translation rights income makes up. In 2014, 36 million GBP were generated by translation contracts, which accounted for $31 \%$ of the complete industry rights income [50]. However, the Publishers Association Statistics Yearbook does not differentiate between genres, so the proportion of fiction, children's literature, textbooks, etc. remains unclear, as do the target countries and languages. This is a further sign that translations are considered less important in the UK than in Germany, for instance.

This will come as no surprise to scholars of publishing and book history as well as industry practitioners. For native English speakers, or those who do not read translations, this can have serious implications because it can perpetuate, as Edith Grossman states, "our tendency toward insularity and consequent self-imposed isolation" [28]. Translations can, Grossman continues, help readers "explore through literature the thoughts and feeling from another country or another time. It permits us to savor the transformation of the foreign into the familiar and for a brief

${ }^{2}$ What this contribution will not and cannot do, however, is introduce readers to German literary trends. We highly recommend Katharina Gerstenberger and Patricia Herminghouse's introduction to German Literature in a New Century for this purpose [26]. 
time to live outside our own skins, our own preconceptions and misconceptions"

112 [30].

113 Despite a general consensus that translations can fulfill a significant role, 114 mediating between cultures, languages and translations in an increasingly global115 ized world, "The UK bestseller market is [...] by far the most averse against 116 translations" [38]. But this does not only apply to the UK bestseller lists, but rather 117 to the industry more widely. Regarding actual numbers, there is a metaphorical 118 number which crops up repeatedly: only $3 \%$ of books in the English-speaking 119 world are translations. Sometimes, the dearth of translations in the English-speaking 120 world is called the "Three Percent Problem" [49]. In 2013, in order to understand 121 more precisely where this number came from and whether it was correct, Jasmine 122 Donahaye from the initiative "Literature Across Frontiers" put together the 123 feasibility study Three percent? Publishing data and statistics on translated 124 literature in the United Kingdom and Ireland [17]. The objective of the study, 125 Donahaye explained, "was to recommend a solution to the problem of lack of 126 translation statistics in the UK and Ireland in the form of a proposal concerning the 127 collection, processing, sharing and analysis of data on published literary transla128 tions, in order to facilitate future research and assessment of trends" [18]. Thanks to 129 Donahaye and the "Literature Across Frontiers" initiative (funded in part by the EU 130 and the Arts Council England), we finally have substantive data on translations in 131 the UK. The study is based on British National Bibliography and British Library 132 catalog data for 2000, 2005 and 2008. Using this data, Donahaye was able to show 133 that circa $2.5 \%$ of all publications in the United Kingdom and $4.5 \%$ of published 134 literature (that is, fiction, poetry and drama) are translations [20]: "As the data 135 clearly indicates, literary translation in the UK and Ireland-whether assessed 136 according to its broader definition or restricted to the genre categories of poetry, 137 fiction and drama-is a little higher than the often-cited $3 \%$ figure. Indeed it is 138 consistently greater than $4 \%$, and, over the sample years, consistently increases."

139 Nonetheless, even $4 \%$ is significantly lower than the percentages in Germany, for 140 instance, where roundabout $25 \%$ of fiction titles are translations (2014: $26.6 \%$ 141 [12]). Donahaye was also able to show that the most frequent source languages are 142 French, German, and Spanish [19, 21]. Whereas we know from Buch und 143 Buchhandel in Zahlen that roundabout $70 \%$ (2014: $70.2 \%$ [11]) of literary 144 translations in Germany come from English (AE, BE, other variants), we do not 145 have comparable figures for the proportion of German-language books amongst 146 literary translations published in the UK and Ireland.

\section{Categories of Translated German Fiction}

148 In her 2010 article "A New Great Wall: Why the Crisis in Translation Matters", 149 Grossman explained:

150 The dearth of translated literature in the English-speaking world represents a 151 new kind of iron curtain we have constructed around ourselves. We are 152 choosing to block off access to the writing of a large and significant portion of 
the world, including movements and societies whose potentially dreadful political impact on us is made even more menacing by our general lack of familiarity with them. Our stubborn and willful ignorance could have-and arguably, already has had-dangerous consequences. The problem starts in the Anglophone publishing industry, where translated books are not only avoided but actively discouraged [32].

In her case study of the translation of award-winning novels, Susan Pickford noted the issue of the dominance of the English language in the global marketplace: "[T]he place allotted to literature in translation in a given culture depends on the relative degree of cultural dominance between the two languages." She also commented that the costs involved in translation inhibit publishers from commissioning foreign titles: "Increasing concentration and competition in the publishing world mean that mainstream UK-US publishers are turning their backs on translation, which inevitably involves costs in terms of rights acquisition and translation fees, while the sales potential of translated titles is perceived as being limited" [48]. According to numbers put forth by John Thompson, an Anglophone publisher must sell 5000 copies of a translated title to cover rights and translation costs in addition to the regular production costs. Yet Thompson claimed that translations only sell about 1500-6000 copies; he also noted that even 5000 copies sold are considered niche publishing in the Anglophone world and would be written off as a bitter disappointment by conglomerates [59].

In Publishing Perspectives, Esther Mallm, foreign rights manager at S. Fischer Verlage (Holtzbrinck), recently stated, "One of the greatest obstacles in finding partners to publish German books [...] is the simple fact that very few editors read German themselves so they have to rely on the opinion of a third party in order to make a favorable decision" [52]. Connie Hsu, editor at Little, Brown and Company in the US, confirmed that the "discoverability of a title" is the problem for her: "It's hard to consider a foreign title without reading the manuscript in full, and unfortunately, foreign publishers are understandably wary of investing in a full translation without a guarantee of a sale" [52].

Grossman emphasizes the fact that publishers like to pretend that translations are not marketable. Most English-language publishers will argue that there is no demand for these translations and that "English-language readers are put off by translations" [29]. Grossman's explanation for this phenomenon is in the form of a chicken-and-egg situation: is the limited readership for translations the reason so few translated books are published or is the readership limited because so few translated books are published? She underlines the fact that availability and visibility are key factors in determining the marketability of a product. If publishers do not show interest and make translated literature available, where are the readers going to find it? Peter Ayrton, the founder of the independent publisher Serpent's Tail, concurred with Grossman's analysis, "There's a general perception in the trade that these books can be difficult to sell [...] and as long as that persists it's a selffulfilling prophecy" [39]. Christopher MacLehose (MacLehose Press) said that mainstream publishers have a particularly asinine argument for not publishing 
translations, "The idiotic notion is that there's enough being written in English" [39].

In order to better understand which types of books are able to cross the channel from Germany to the UK, a corpus of relevant titles has been identified and collected on the basis of the British Library's British National Bibliography (BNB) database. The British Library is one the UK's legal deposit libraries; so all books published in the UK should be registered here. The research corpus includes all works of fiction that fall under BIC classification 'F: Fiction and Related Items', irrespective of genre. The BNB database was searched for German fiction published by in the UK (or a publisher with an office in the UK) since 2000. The list was then examined for duplicates and titles that did not fit within BIC classification F. This ongoing collection of titles provides an overview of the key titles, trends, publishers, and translators involved in the transfer of German fiction into the UK market.

So far, we have identified these different main categories of translated German fiction:

\section{Steadysellers and classics}

Esther Allen, the executive director of Columbia University's Centre for Literary Translation, said about the crisis of translation in English "The number of novels being published in translation is ridiculously small [...]. If you sort out the authors who are already globally validated-Nobel winners and so on-and the retranslations of the classics, then it's absurd." [39] The first group of translated titles are exactly these steadysellers and classics which have been canonized and are thus made available over and over again, republished on the occasion of anniversaries, birthdays, and the like. "All general translation data demonstrate how little is translated in[to] English, if compared to other target languages; and yet more of the 'elite' authors are available in English than generally assumed" [37]. For German fiction in translation, this applies to modern classics like Siegfried Lenz as well as the 20th- and 21st-century Nobel Prize winners Heinrich Böll, Günter Grass and Herta Müller. Classics naturally include Schiller and Goethe. Since these texts are out of copyright, there are multiple editions by a variety of publishers.

\section{Bestsellers}

Often-and more surprisingly_German fantasy and thriller authors make their way across the channel. In our database, names such as Markus Heitz with his Dwarf novels (German publisher: Piper, Orbit; UK publisher: Little, Brown Book Group) or Sebastian Fitzek (German publishers: Lübbe and DroemerKnaur; UK publisher: Atlantic Books) and Frank Schätzing (German publisher: Kiepenheuer \& Witsch; UK publisher: Quercus) with their highly readable but probably rather short-lived bestselling thrillers pop up regularly. Crossover authors, whose writing 
appeals to young adults ${ }^{3}$ as well as not-so-young adults, are also well-represented in

240 the list: "The crossover phenomenon has $[\ldots]$ helped to bring some foreign authors to the attention of the English-speaking world and even to put them on bestseller lists, one of the most notable examples being Cornelia Funke" [3]. Funke with her Inkworld trilogy (German publisher: Oetinger; UK publisher: ChickenHouse Scholastic) and countless other books has successfully tapped in English markets and even into Hollywood. Historically speaking, an author who falls into this category is Michael Ende with his book The Neverending Story. Contemporary authors who also belong to this category are Walter Moers with his Zamonia books (German publisher: Knaus; UK publisher: Harvill Secker/Penguin Random House) and Kai Meyer with his fantasy trilogies (German publishers: Carlsen, Heyne, Loewe and Fischer Jugendbuch/FJB; UK publisher: Egmont).

3. "Do mention the war!"

A clearly identifiable theme is what we like to call "Do mention the war!" books, a tongue-in-cheek reference to the famous line from the classic BBC comedy sitcom Fawlty Towers: "Don't mention the war!" There is an obvious preference of British readers for fiction dealing with the World Wars and Nazi Germany. Anthea Bell $\mathrm{OBE}$, one of the most prominent translators from German into English, is a keen observer of the market for translations in the UK. She has repeatedly shared her impressions on British readers' tastes. "If you translate from German, you get a lot of material to do with the Nazi period and the Holocaust," she said in 2011 [40]. Marion Löhndorf also confirmed this longstanding trend in the Neue Zürcher Zeitung in 2012 [42].

A recent and particularly interesting example is the better-late-than-never translation of Hans Fallada's book Everyman Dies Alone/Alone in Berlin, which depicts the everyday working-class life in Nazi Germanyand incorporates the true story of Otto and Elise Hempel, who wrote and distributed dissident postcards and were eventually caught, tried and beheaded for their resistance to the regime. The book was published in Germany in 1947 and never translated into English-until 2009. Michael Hofmann's translation was well-received and the book's status as a re-discovery from the past made it a surprising runaway bestseller in the UK and even in the USA with hundreds of thousands copies sold. In the Guardian, Sam Jordison wrote "it's an important book that no English writer could have writtenand so another resounding argument for the importance of taking in translations. It makes me wonder what else we've been missing" [35].

Timur Vermes' satirical novel Er ist wieder da/Look Who's Back (German publisher: Eichborn; UK publisher: MacLehose Press) is a premier example of this category. In the novel, Adolf Hitler wakes up in 2011 in Berlin and becomes a

\footnotetext{
${ }^{3}$ There has been an unprecedented boom of children's and young adult books in translation in the last few decades, paired with a rise in scholarly interest in the area. The wide range of literature available on the topic presents the numerous advantages of translations put forward by scholars. One of the most recognized values of children's and young adult translations is that they create new settings for children's and young adults' imaginations to develop and are important tools in promoting cultural understanding. Regarding translation of children's literature [27, 44, 45, 57].
} 
comedian and YouTube star with a reputation for never breaking character as a

279 Hitler impersonator. The book has been translated into roughly 40 languages and 280 even recently appeared in Israel [33]. The "sassy translation" by Jamie Bulloch 281 appeared in 2014, following much international media attention [60]. For instance, 282 even before the English translation was available, the BBC asked in response to the 283 publication of the original German version in 2013, of which over 2 million copies 284 have been sold, "Can the Führer be funny?" [25]. Guardian writer Philip Olterman 285 stated, "there's no question that the novel has hit upon the key paradox of our modern obsession with Hitler". In the meantime, the book has been made into a film in Germany and has sold extraordinarily well for a book that Olterman says is "a bit 288 of a slog" [47].

\section{A potpourri of contemporary German fiction}

Contemporary German fiction can offer UK readers insight into contemporary German society. These books can share new perspectives on post-reunification Germany. Contemporary German fiction in translations can help readers surpass the stereotypes: past WWII, beyond bratwurst, Christkindelmarkt, Oktoberfest, and Angela Merkel. Thus, contemporary German fiction can be an important puzzle piece towards understanding in a changing Europe and world. Names that come to mind are, for instance, Clemens Mayer, who was born in the German Democratic Republic in 1977 or Jakob Arjouni, with/his crime novels featuring a secondgeneration immigrant from Turkey as a detective.

But what sorts of German fiction make it across the channel besides the aforementioned classics, steadysellers, bestselling thrillers, fantasy novels, and fiction about Nazi Germany? Katy Derbyshire, a translator specialized in German fiction, recently pinpointed the gender inequality in translated fiction in the Guardian, "Translated novels by female writers are the palomino unicorns of the publishing world - not just unusual, but a small subset within a subset. Not only do translations make up a tiny fraction of the books brought out in the UK and US, but only about a quarter of them are by women" [15]. Contemporary German female writers such as Monika Held, Karen Duve or Julia Franck have crossed the channel, but as our preliminary findings show, they are few and far between. In her insightful article, Derbyshire looked for reasons for this imbalance and noted that until recently, novels translated from the German "tended to be cerebral literary novels", which was often (incorrectly) associated mainly with male authors, and "more commercial or accessible writing simply wasn't crossing the language barrier" [15]. She is not the only book industry observer who has identified a recent shift in content and style in translated fiction. In 2005, Carter Dougherty wrote in the New York Times that the new German novel was becoming "less weighty and more exportable", naming for instance Sven Regener or Daniel Kehlmann. "Having eschewed the traditional model of heavy, politics-laden prose in favor of light, even lively storytelling, German authors are in the midst of a breakthrough that is propelling their work to hitherto unfound success abroad" [22].

There are a number of actors involved in this process, if indeed we can consider it as a breakthrough. The German authors themselves have become active players in 
the translation market: "Once content to write for a small circle of readers at home, they have tuned their antennae toward the rest of world, testing out ideas on publishers with an eye toward eventual sales abroad" [22]. Translators are advocates for books in translations, out of idealism and, naturally, out of good business sense. Besides Anthea Bell OBE, other renowned British translators of German fiction are Sally-Jane Spencer, Michael Hofmann, John Maxwell Brownjohn, Jamie Bulloch, and Katy Derbyshire. Derbyshire lives in Berlin and writes about her work as a translator and scout of new German fiction on her blog called Love German Books [16]. Together with the British indie publisher And Other Stories [1], she has conducted reading groups in Berlin, which can be considered "editorial crowd-sourcing" for translations [14].

Indie publishers such as And Other Stories have proven to be safe havens for novels in translations from all sorts of languages. In the past 10 years, British indie publishers have welcomed literature from a variety of backgrounds into their programs. Donahaye [17] lists publishers (conglomerate and indie) that publish translations more generally. As regards to German fiction, there are some that have a special connection, such as Haus Publishing, founded in 2003 by Barbara Schwepcke, a German-born journalist. So far, however, no UK indie publisher has been founded that only specializes in German(-language) fiction, whereas there is a specialized UK publisher for French books: Gallic Books, founded in 2007 by two former Random House editors, Jane Aitken and Pilar Webb.

Whether conglomerate or indie, both types of publishers are happy to accept translations subsidies from the Goethe Institute [61] and the London-based initiative "New Books in German" (NBG) [43]. NBG, founded in 1996, functions as an independent intermediary addressing publishers in the UK and the US to encourage them to commission more translations of books written in German by providing an overview of the thousands of new titles published in Germany, Austria and Switzerland each year. Consisting of a periodical and a website (launched in 1999), NBG offers impartial orientation and guidance for readers of English, not only focusing on private consumers or editors from publishing houses, but also trying to generate attention for the selected titles among participants from every branch of the UK and US book trade, such as translators, literary critics and journalists, booksellers, German departments in universities and libraries [43]. The magazine introduces an average of 35 titles per issue to give a preselected overview of the German-language book market covering fiction, non- fiction, and young-adult titles-many of them standing out as highbrow literature due to either winning the German Book Prize or being short-respectively longlisted for the award. Published twice a year by the British Center for Literary Translation, the spring issue coincides with the London Book Fair and the autumn issue appears just in time for the Frankfurt Book Fair. The magazine, distributed primarily throughout the Anglophone language area by the London-based office, the Goethe-Institut, the Austrian, German and Swiss embassies, the Frankfurt Book Fair and the German Book Office in New York, contains reviews of contemporary German-language books, that are chosen and reviewed by the editorial committee, consisting of different guest members or editorial advisors, such as UK editors, publishers, booksellers, scouts or agents, but mostly of representatives of NBG's sponsors. Financial support is 
afforded by institutions from all three countries - the Foreign Ministries of Austria, Germany and Switzerland, Pro Helvetia, the Arts Council of Switzerland, the Goethe-Institut in Munich and London, the German Book Office in New York, the International Division of the Frankfurt Book Fair and the German Publishers \& Booksellers Association. Besides these funds, a contribution to the magazine costs is made by German publishers for each book featured.

In addition to actual funding, prizes function as symbolic capital, which make books more marketable and attractive for translation [8, 23, 58]. As Rebecca Braun stated, the German Book Prize, founded in 2005, "explicitly aims at being used as a promotional tool to help an author move beyond the German frame of literary valuation" [9]. Braun argued convincingly that "unlike the many named regional and national prizes that seek to tie an author to a geographical place and/or a cultural tradition, the award [the German Book Prize] deliberately does not reward authors for fitting in with a pre-existing, normative understanding of German culture. Instead, it aims to construct both authors and their work as cultural ambassadors, who, in their anticipated international success, will help shape an understanding of German culture as inherently embedded in wider global discourse" [9]. In her analysis of the impact of the prize on German-language fiction abroad Sally-Ann Spencer confirmed that the award had a positive effect on overseas adoptions "not least through its assertion that German-language fiction deserves international prizing" [56].

As Ghesquire [27] stated, a number of factors influence the decision for the purchase of translation rights, including the popularity of a book in the original language. And of course, the German Book Prize winners are not all equally successful in the original language and regarding translations. While the Book Prize guarantees media attention and the books normally sell quite well, not all of them become immediate bestsellers. Krechel's complex and very long novel Landgericht (2012), for instance, has not been translated into any language, whereas Franck's Die Mittagsfrau/The Blind Side of the Heart (2007, transl. 2009) has been translated into roughly two dozen languages in a multitude of editions.

Analysis of the current translation statistics for the German Book Prize, based on 400 the data in the German National Library catalog and on information on publishers' 401 websites, showed that $46 \%$ of the prizewinners haven been or will appear with 402 publishers based exclusively or with a base in the UK. Over $60 \%$ of the 403 prizewinners have been translated into English or the English-language rights have 404 been sold. Considering the low percentage of translations into English in general, over $60 \%$ is an impressive quota.

2005 Arno Geiger, Es geht uns gut, Hanser

Maria Poglitsch Bauer, Ariadne Press (CA/USA), 2011

4132006 Katharina Hacker, Habenichtse,

Helen Atkins, Europa Ed. (NY/USA), 2008 Suhrkamp

4142007 Julia Franck, Die Mittagsfrau, S. Fischer

Anthea Bell, Harvill Secker, 2009

415

2008 Uwe Tellkamp, Der Turm, Suhrkamp

Mike Mitchell, Allan Lane, 2014 


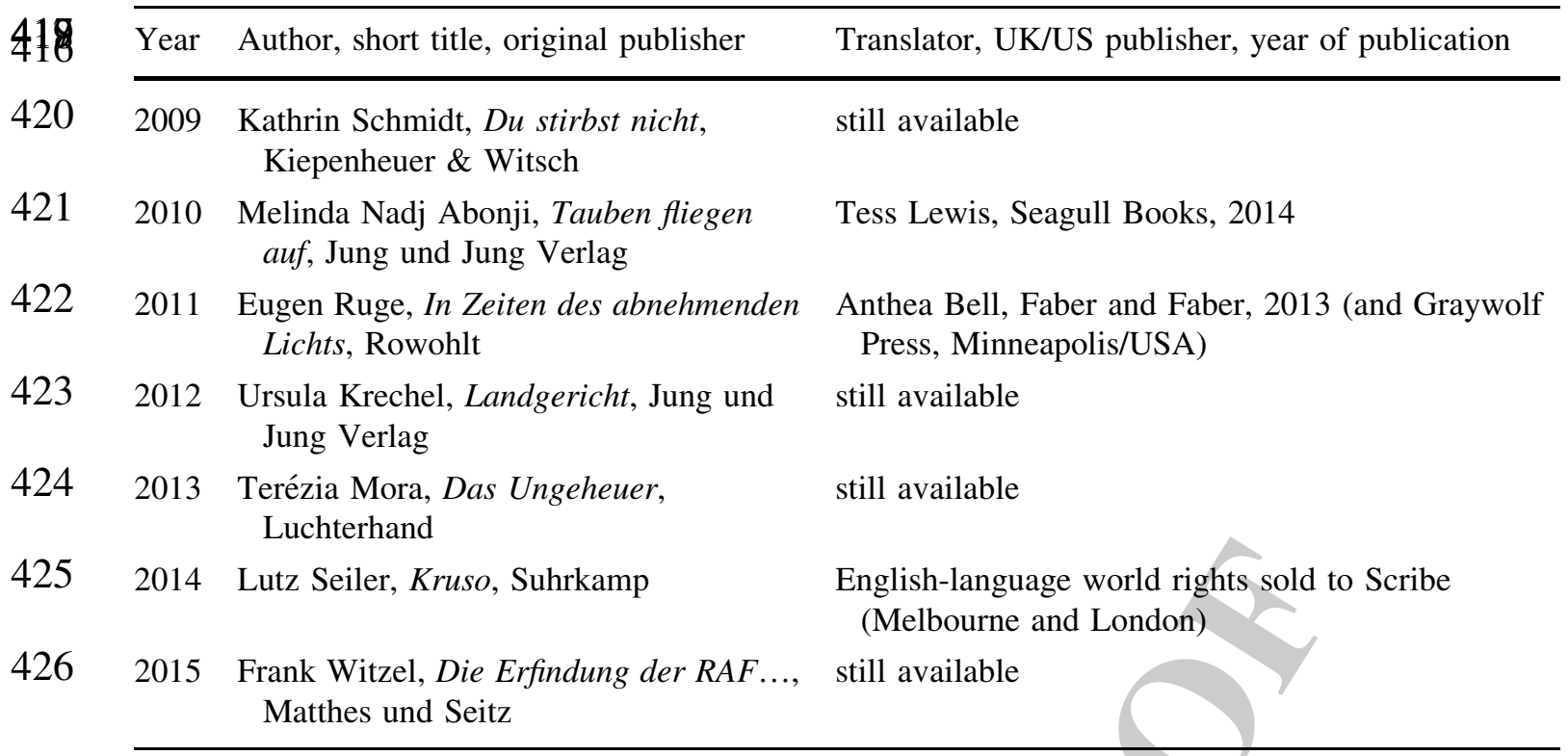

\section{Conclusions and Outlook}

429 As the British publishing industry becomes increasingly concentrated into the hand 430 of fewer, large conglomerates, more niche (and unprofitable) areas of publishing, 431 such as translation, tend to be overlooked. Translation in the book publishing 432 industry is an interesting and evolving area of research, despite its comparatively 433 marginal economic significance in the UK market. Nonetheless: although the British 434 publishing industry falls well below its German counterpart with regards to the 435 number of translations it publishes, it does publish (slightly) above the oft-quoted $4363 \%$.

437 This paper, primarily based on the preliminary findings of our research and 438 literature review, gives a broad overview of the relationship between the British 439 publishing industry and German books: a field that has been hitherto ignored and not 440 treated sufficiently. Our preliminary research identified four main categories for 441 German fiction translated into English. As this paper has shown, the Anglo442 American publishing industries continue to fall behind their non-English-language 443 colleagues in terms of language diversity in cultural output. This homogenization of 444 the market has many implications for a nation's readers, for example many scholars 445 have argued that translations are a tool for cultural awareness and understanding $446[27,28,44,57]$. There are, however, a number of structures and mechanisms in 447 place that support and promote translated (German) books, some of which [i.e. 448 literary prizes, dedicated websites and magazines, funding etc.] have been discussed 449 in this paper. The director of the British Centre for Literary Translation, Amanda 450 Hopkinson, has said that she detects "positive signs" in the UK, identifying a 451 "groundswell of opinion from the grass roots [...] which we should be taking notice 452 of". For Hopkinson, translation is a crucial tool for promoting mutual understand453 ing. "We shouldn't be discussing other cultures through English culture," she 
emphasized, in 2007, "we should be discovering their own cultures, what they have to say for themselves" [39].

Grossman [31] has argued that translations are important for all parties involved (author, publisher and consumer/reader); therefore more extensive research (including interviews with the key actors involved in the publication, distribution and reception of German books in the UK) will be conducted to treat the topic more thoroughly. Our forthcoming research will explore these issues and concepts in more depth.

This case study can be understood as one stepping-stone towards a more comprehensive understanding of the culture of translation in the UK. A logical next step within the framework of our German-British case study will also be a comparison of the cultural and literary exchange between the two countries, that is, an analysis of the types of English-language books translated into German and the actors involved in this process. Beyond this particular case study, with a view towards understanding the subtle and not-so-subtle differences in European culture(s) of translation, we would welcome a comparison of our results with data on the types of French, Spanish, Italian, Polish, Swedish etc. books which make their way into British bookstores in translation.

\section{References}

1. And Other Stories. Reading groups. http://www.andotherstories.org/reading-groups/. Accessed 11 April 2016.

2. Bachleitner N, Wolf M. Zur soziologischen Erforschung der literarischen Übersetzung im deutschsprachigen Raum. In: Bacheitner N, Wolf M, editors. Streifzüge im translatorischen Feld. Zur Soziologie der literarischen Übersetzung im deutschsprachigen Raum. Berlin, Münster, Wien: LIT; 2010. p. 7-29, cf. in particular p. 8.

3. Beckett SL. Crossover fiction: global and historical perspectives. New York: Routledge; 2009, 229.

4. Bellos D. Is that a fish in your ear? The amazing adventure of translation. London: Penguin; 2012.

5. Ibid, 210.

6. Ibid, 211.

7. Bender U. Zwischen Autorenbetreuung und transatlantischem Literaturgeschäft. In: Fischer E, editor. Literarische agenturen: die heimlichen Herrscher im Literaturbetrieb?. Wiesbaden: Harrassowitz; 2001. p. 41-9.

8. Bourdieu P. The field of cultural production: essays on art and literature. Cambridge: Polity Press in Association with Blackwell; 1993.

9. Braun R. Prize Germans? Changing notions of Germanness and the role of the award-winning author into the twenty-first century. Oxf Ger Stud. 2013;43(1):37-54, 47.

10. Buch und Buchhandel in Zahlen. Frankfurt: MVB; 2015, 103.

11. Ibid, 97.

12. Ibid, 102.

13. Ibid, 104.

14. Demarco A. Case study: and other stories' "Editorial Crowd-sourcing" for Translations. Publishing Perspectives, September 7, 2012. http://publishingperspectives.com/2012/09/case-study-and-otherstories-editorial-crowd-sourcing-for-translations.

15. Derbyshire K. Translation fiction by women must stop being a minority in a minority. Guardian, March 10, 2016. http://www.theguardian.com/books/booksblog/2016/mar/10/translated-fiction-bywomen-must-stop-being-a-minority-in-a-minority. Accessed 11 April 2016.

16. Derbyshire K. Love German books. Biased and unprofessional reports on German books, translation issues and life in Berlin. http://lovegermanbooks.blogspot.de/. Accessed 11 April 2016. 
17. Donahaye J. Three percent? Publishing data and statistics on translated literature in the United Kingdom and Ireland. Aberystwyth: Mercator Institute for Media, Languages and Culture; 2013. http://www.lit-across-frontiers.org/wp-content/uploads/2013/03/Publishing-Data-and-Statistics-onTranslated-Literature-in-the-United-Kingdom-and-Ireland-A-LAF-research-report-March-2013-final. pdf. Accessed 11 April 2016.

18. Ibid, 3.

19. Ibid, 4.

20. Ibid, 28 .

21. Ibid, 48-49.

22. Dougherty C. The New German novel: less weighty, more exportable. New York Times, December 20, 2005. http://www.nytimes.com/2005/12/20/books/the-new-german-novel-less-weighty-moreexportable.html. Accessed 11 April 2016.

23. English JF. The economy of prestige. London: Harvard University Press; 2009.

24. European Book Publishing Statistics. 30 November 2015. http://www.fep-fee.eu/IMG/pdf/european_ book_publishing_statistics_2014.pdf. Accessed on 17 March 2016, 1.

25. Evans S. Timur Vermes' Hitler novel: Can the Führer be funny? BBC, 2 May, 2013. http://www.bbc. com/culture/story/20130417-is-it-okay-to-laugh-at-hitler. Accessed 11 April 2016.

26. Gerstenberger K, Herminghouse P. Introduction. In: Gerstenberger K, Herminghouse P, editors. German literature in a New Century, trends, traditions, transitions, transformations. New York: Berghahn; 2008. p. 1-11.

27. Ghesquire R. Why does children's literature need translations? In: Van Coillie J, Verschueren WP, editors. Children's literature in translation: challenges and strategies. Manchester: St. Jerome Publishing; 2006. p. 19-34.

28. Grossmann E. Why translation matters. New Haven: Yale UP; 2011. p. 55.

29. Ibid, 28.

30. Ibid, 14.

31. Ibid, 6.

32. Grossman E. A new great wall: why the crisis in translation matters. Foreign Policy, April 26, 2010. http://foreignpolicy.com/2010/04/26/a-new-great-wall/. Accessed 11 April 2016.

33. Haupt F. Hitler in Israel. Frankfurter Allgemeine Zeitung. March 18, 2016. http://www.faz.net/ aktuell/politik/bestseller-er-ist-wieder-da-hitler-in-israel-14132342.html. Accessed April 11, 2016.

34. Jahnsen D. Germany a foreign rights dwarf? Publishing Research Quarterly. 2007;23(2):146-50.

35. Jordison S. English readers don't know what we've been missing. Guardian, March 9, 2009. http:// www.theguardian.com/books/booksblog/2009/mar/09/english-translation-fallada. Accessed 11 April 2016.

36. Kessel M. Importartikel Buch: Zwischen Nischengeschäft und „heißen Titeln“. In: Arnold HL, Beilein M., editors. Literaturbetrieb in Deutschland. Munich: edition text + kritik; 2009. p. 421-32.

37. Kovač, M, Wischenbart, R. Diversity report 2009. Cultural diversity in translations of books: mapping fiction authors across Europe. Vienna: CulturalTransfers.org; 2009. http://www. wischenbart.com/upload/Diversity_Report_2009.pdf. Accessed 11 March 2016, 33.

38. Ibid, 31.

39. Lea R. Lost: translation. Guardian, November 16, 2007. http://www.theguardian.com/books/2007/ nov/16/fiction.richardlea. Accessed 11 April 2016.

40. Lear E. Q\&A with Anthea Bell. Publishers Weekly, May 19, 2011. http://www.publishersweekly. com/pw/by-topic/authors/interviews/article/47327-q-a-with-anthea-bell.html. Accessed 11 April 2016.

41. Lepape P. Lost without translation. English-language books dominate world publishing. Le Monde diplomatique. English Edition LMD. May 2004. http://mondediplo.com/2004/05/15literature. Accessed 11 April 2016.

42. Löhndorf M. Neue deutschsprachige Literatur sucht ihren Platz in Großbrittanien. Die Stieftochter emanzipiert sich. Neue Zürcher Zeitung, November 19, 2012. http:/www.nzz.ch/aktuell/feuilleton/ literatur/neue-deutschsprachige-literatur-sucht-ihren-platz-in-grossbritannien-1.17817151. Accessed 11 April 2016.

43. New Books in German. http://www.new-books-in-german.com. Accessed 11 April 2016.

44. Oittinen R. Translating for children. New York: Garland; 2000.

45. Oittinen R. No innocent act: On the ethics of translating for children. In: Van Coillie J, Verschueren WP, editors. Children's literature in translation: challenges and strategies. Manchester: St. Jerome Publishing; 2006. p. 35-46. 
561

562

563

564

565

566

567

568

569

570

571

572

573

574

575

576

577

578

579

580

581

582

583

584

585

586

587

588

589

590

591

592

593

594

595

46. Owen L. Selling rights. 7th ed. Routledge: Abingdon-on-Thames; 2014.

47. Oltermann P. Germany asks: Is it OK to laugh at Hitler? Guardian, 23 March, 2014. http://www. theguardian.com/books/2014/mar/23/germany-finally-poke-fun-hitler-fuhrer. Accessed 11 April 2016.

48. Pickford S. The booker prize and the prix goncourt: a case study of award-winning novels in translation. Book History. 2011;14:221-40, 225.

49. Post CW. The three percent problem: rants and responses on publishing, translation, and the future of reading. Rochester: Open Letter; 2011.

50. Publishers Association Statistics Yearbook. London: Publishers Association; 2015, 89.

51. Rectanus M. German literature in the United States. Licensing Translations in the International Marketplace. Wiesbaden: Harrassowitz; 1990.

52. Rosenthal B. Opening the floodgates for translation. Publishing perspectives, August 1, 2013. http:// publishingperspectives.com/2013/08/opening-the-floodgates-for-translations/. Accessed 11 April 2016.

53. Rude-Porubská S. Förderung literarischer Übersetzung in Deutschland. Akteure - Instrumente Tendenzen. Wiesbaden: Harrassowitz; 2014.

54. Smerillo D. Selling translation rights. Publishing Research Quarterly. 2008;24(4):285-93.

55. Smerillo D. Selling translation rights to an American publisher. Publishing Research Quarterly. 2009;25(3):181-90.

56. Spencer SA. Prizing translation: book awards and literary translation. In: Nelson B, Maher B, editors. Perspectives on literature and translation: creation, circulation, reception. New York: Routledge; 2013. p. 195-209, 205.

57. Stolze R. Translating for children: World view or pedagogics? Meta. 2003;48(1-2):208-21.

58. Squires C. Marketing literature: the making of contemporary writing in Britain. Basingstoke: Palgrave Macmillan; 2007.

59. Thompson JB. Merchants of culture. The publishing business in the twenty-first century, second edition. New York: Plume; 2012, 195.

60. Tonkin B. Timur Vermes's looks who's back: Is it ever safe to laugh at Hitler? The Independent. 2 April 2014. http://www.independent.co.uk/arts-entertainment/books/features/timur-vermess-lookwhos-back-is-it-ever-safe-to-laugh-at-hitler-9233999.html. Accessed April 11, 2016.

61. Translation Grant Programm of the Goethe-Institut. http://www.goethe.de/kue/lit/prj/uef/enindex. htm. Accessed 11 April 2016.

62. UNESCO: Index Translationum. World bibliography of translation. http://www.unesco.org/xtrans/ bsform.aspx. Accessed 11 April 2016.

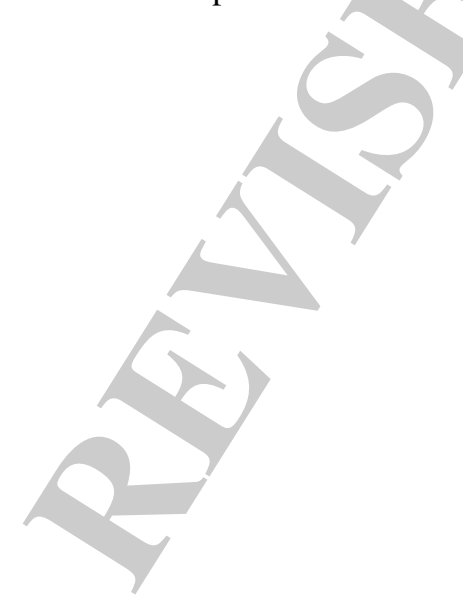

